\title{
Arsine poisoning
}

\author{
A. G. HOCKEN and G. BRADSHAW \\ Hull Royal Infirmary (Sutton) and Capper Pass \& Son Ltd., North Ferriby, Yorkshire
}

\begin{abstract}
Hocken, A. G., and Bradshaw, G. (1970). Brit. J. industr. Med., 27, 56-60. Arsine poisoning. A case of acute arsine poisoning is described, occurring in an industrial metallurgy worker. The clinical course was of associated oliguric renal failure with acute haemolytic anaemia which was self-limiting but accompanied by marked non-thrombotic phlebitis. There was minor hepatocellular damage. Skin pigmentation was disproportionate to the elevation of serum bilirubin. Transient initial pulmonary oedema was regarded as a local irritative phenomenon.

All systems underwent complete recovery. Renal function in particular was explored in all modalities, and no abnormality could be found in glomerular filtration, concentrating power or acidification 12 months after exposure. There was no proteinuria. The clinical picture was of acute tubular necrosis, although interstitial fibrosis was present and its incomplete final resolution is possible.

Contrary to the findings of other workers, no evidence was found of myocardial damage at any stage either clinically or electrocardiographically.
\end{abstract}

Arsine $\left(\mathrm{AsH}_{3}\right)$ poisoning is a recognized industrial hazard (Buchanan, 1962), producing poisoning at less than $30 \mathrm{ppm}$, a concentration far below that at which its faint smell of garlic is detectable. The recommended threshold limit in this country is $0.05 \mathrm{ppm}$ (Ministry of Labour, 1966a, b). Industrial arsine poisoning was first recorded in 1900 by the Chief Inspector of Factories. Between 1900 and 1959, 120 cases were reported, of which $27(32 \%)$ were fatal (Buchanan, 1962).

The present case is presented to recall arsine as a cause of industrial poisoning. Few practitioners will see two cases, in two separate incidents of poisoning, as that individual referred to by Doig (1958). The present patient has run a predictable course with the exception of the feature of acute phlebitis, associated with haemolytic stage, which we have not seen described elsewhere.

\section{Case report}

The patient, a 47-year-old man employed in a metal smelting and extraction firm, was admitted as an emergency at 10.00 a.m. with complaints of jaundice, vomiting, and blood-stained urine. Twenty-four hours previously, he had descended an industrial drain to release an obstruction, carrying a galvanized bucket and spade. Upon release of the obstruction, fumes filled the manhole. On emerging at approximately 12.15 p.m., the patient vomited and was breathless, with an irritated upper respiratory tract and watering eyes. The immediate symptoms passed quickly, and, having eaten lunch, he was well until 3.15 p.m. when he felt chilled and passed urine for the first time since exposure. He noted it to be heavily blood-stained. An hour later he finished work and cycled home, a journey of approximately three miles, at the end of which he had a pain in the chest and a choking sensation, which forced him to walk the remaining short distance. On arrival he vomited. That night, getting up to vomit, he noticed that he was jaundiced. By the following morning the vomiting had ceased.

On admission to hospital, his temperature was $99.6^{\circ} \mathrm{F}$. He was deeply jaundiced but also exhibited a dusky cyanosis. The skin over the moderately varicose veins of both lower legs was dark red. The veins were proud and tender. There were bilateral crepitations in the lung fields. The liver was palpable and tender. The blood pressure was $140 / 90 \mathrm{mmHg}$, and no abnormal signs were noted in the cardiovascular system. Investigations indicated a blood urea of $115 \mathrm{mg} / 100 \mathrm{ml}$, heavy proteinuria (greater than $1000 \mathrm{mg} / 100 \mathrm{ml}$ ), $2.7 \mathrm{~g} / 100 \mathrm{ml}$ haemoglobinuria 
with no abnormal sediment. Whole blood haemoglobin was $11.7 \mathrm{~g} / 100 \mathrm{ml}$ with a plasma haemoglobin of 2.5 $\mathrm{g} / 100 \mathrm{ml}$. Liver function tests indicated all sero-flocculation tests to be abnormal. The chest radiograph showed peri-hilar congestive changes.

\section{Progress and treatment}

\section{Liver function}

The jaundice faded rapidly. The sero-flocculation tests were constantly moderately disturbed. One month after poisoning, the serum alanine aminotransferase was normal, whilst the total serum globulin was raised at $4.3 \mathrm{~g} / 100 \mathrm{ml}$. The latter persisted, and four months after injury the serum proteins were albumin $4.2 \mathrm{~g}$., alpha $10.3 \mathrm{~g}$., alpha 2 $0.8 \mathrm{~g}$., beta $0.8 \mathrm{~g}$., gamma globulin $2.0 \mathrm{~g} / 100 \mathrm{ml}$, while SGPT and SGOT were normal. One month later the total serum protein was $7.6 \mathrm{~g} / 100 \mathrm{ml}$, with the gamma globulin $1.6 \mathrm{~g} / 100 \mathrm{ml}$, the only abnormal level. The coagulation profile was competent. Six months after exposure the liver was palpable and slightly tender. When the patient was last seen, 12 months after poisoning, the liver was clinically normal, the serum proteins were within normal limits, and the gamma globulin was $1.8 \mathrm{~g}$.

\section{Respiratory function}

The chest radiograph taken on the day of admission showed peri-hilar pulmonary shadowing. The patient denied that he was breathless, although he appeared to be quite tachypnoeic. He had had some cough but no copious or stained sputum that might be reminiscent of pulmonary oedema. A small effusion was added to the complex in a radiograph on day 14, at which time he was oedematous. It was already appreciated that the second (delayed) dialysis was indicated. From this time he made an uninterrupted recovery from the chest symptoms.

\section{Cardiovascular system}

Reference has been made to the rapid subsidence of the presenting phlebitis. At no stage, either in the first days after admission or at follow-up, was the electrocardiogram abnormal, contrary to the experience of Josephson, Pinto, and Petronella (1951).

\section{Blood}

At the time of admission gross haemoglobinuria and haemoglobinaemia were present. The red cell destruction, resulting in an acute anaemia, necessitated a transfusion of blood. Twice-daily plasma examination suggested that the haemolysis, in so far as the high level on admission fell consistently, was self-limiting. Once cellular levels of haemoglobin had been restored by transfusion, there was no increase in plasma haemoglobin and no evidence of blood destruction (Fig. 1).

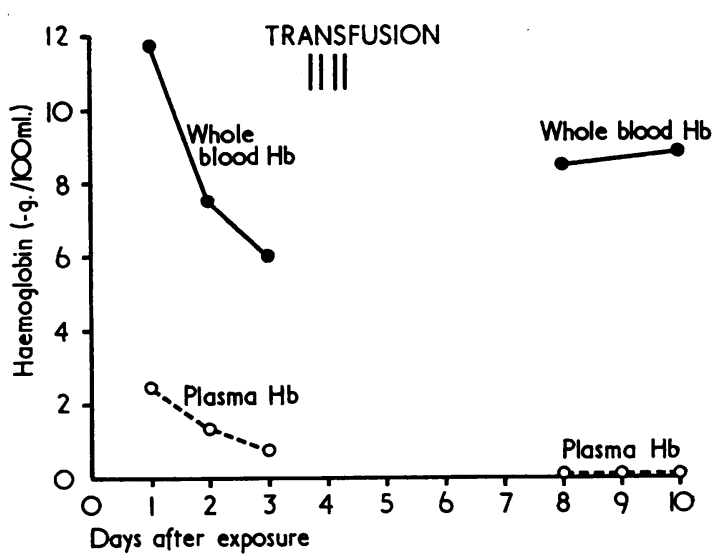

FIG. 1. Disappearance of plasma haemoglobin with time limited intravascular haemolysis in arsine poisoning.

\section{Kidney function}

From before admission to hospital haemoglobinuria was present, and the risk of anuria was recognized. The patient was infused with sodium bicarbonate and saline, an hourly record of urine volumes being kept. Within 12 hours of admission, the urinary output was clearly falling. There was no response to two doses of mannitol, each of $12.5 \mathrm{~g}$ intravenously. The urine volume was at its lowest seven days after admission (500 $\mathrm{ml}$ in 24 hours). From about the eleventh day the urinary volume began to increase. Fluid restriction was maintained until late in the clinical course, and repeated peritoneal dialysis was undertaken.

Azotaemia The blood urea was $115 \mathrm{mg} / 100 \mathrm{ml}$ on admission, 24 hours after exposure. The first peritoneal dialysis was indicated by the azotaemia, rising to $300 \mathrm{mg} / 100 \mathrm{ml}$ and deterioration in the general clinical condition, 72 hours after admission. The second dialysis was delayed for technical reasons. Three further weekly dialyses were instituted each of $40 \times 1$ litre exchanges. The blood urea began to fall spontaneously, four days after the fifth dialysis, and 42 days after exposure. The creatinine clearance fell to $1.8 \mathrm{ml} / \mathrm{min}$ at its lowest, with a serum creatinine of $15.2 \mathrm{mg} / 100 \mathrm{ml}$ at the end of the second week after exposure. It had risen to $85 \mathrm{ml} / \mathrm{min}$, with a serum creatinine of $2.0 \mathrm{mg} / 100 \mathrm{ml}$, five months after injury, and the serum creatinine was $1.8 \mathrm{mg} / 100 \mathrm{ml}$ three months later.

Urinary concentration Concentrating ability was not examined in the acute admission. Four months after exposure, frequency and nocturia persisted to cause the patient to micturate nine times in the course of a day and to get up four times at night. 
Five months after exposure, formal testing with vasopressin revealed an ability to concentrate only to 605 mosm. with a specific gravity of 1.014. A standard short test of urinary acidification (Wrong and Davies, 1959) was given five months after exposure and resulted in a minimum urinary $p \mathrm{H}$ of 5.1. At inpatient review 12 months after exposure, there was no longer nocturia and the vasopressin test was normal.

Proteinuria The progress of proteinuria is recorded in the Table. Electrophoresis suggested high selectivity. By day 152, protein could no longer be detected in the 24-hour urinary volume, and there was no recurrence.

Biopsy No clinical doubt could be entertained here about the diagnosis. The patho-histology of the nephrotoxicity of arsine poisoning is well described, and biopsy was not imperative in the acute stage.

With the abatement of the azotaemia, it appeared, as suggested by proteinuria, frequency, and nocturia, that residual damage might be present. Knowledge of the histology would be advantageous to prognosis and a biopsy was taken five months after exposure.

Histology (Fig. 2) The glomeruli had tuft epithelial hypercellularity. There was increased mesangial material, apparently not involving the basement membranes. Tubules were badly damaged, but irregularly so, with small areas almost intact. The majority showed marked disapproximation and were small in section with low walls. One or two were frankly cystic with casts. The interstitium was grossly disturbed by fibrous tissue, but again this was uneven in distribution.The picture was that of a non-inflammatory (inactive) interstitial fibrosis with disproportionately little glomerular damage.

\section{Discussion}

Arsine is formed when nascent hydrogen is produced in the presence of arsenical compounds, even when the latter are only present as trace impurities. It may be encountered in many industries, particularly during electrolytic processes, the manufacture of zinc chloride and sulphate, the smelting of metallic arsenical ores, the wet treatment of slags, and where impure acids or metals are used.

The accident under review resulted from a combination of circumstances. A drain carrying an acid liquor had blocked, and attempts to clear the blockage from the top of the manhole failed. Normally the liquor flowing in the drain contained sulphur dioxide, creating an atmosphere in which it was impossible to work in the confined space. With the liquor flow stopped due to the blockage, and the manhole cover removed, the sulphur dioxide fumes had dispersed. The patient entered the manhole, which was $4 \mathrm{ft}$ square and $9 \mathrm{ft}$ deep, and, removing the sludge which was blocking the drain, put it into a galvanized bucket. Acid liquor, containing arsenic impurities, reacted with the zinc coating of the bucket and produced arsine. The man was in the manhole for two short periods, estimated at two minutes and five minutes.

The toxic effects of arsine include pulmonary oedema, myocardial damage, intravascular haemolysis, and liver and kidney parenchymal damage (Browning, 1961). The mortality, reported by various authors, ranges from $20 \%$ to greater than $40 \%$ (Browning, 1961). Anuria is associated with

TABLE

Relationship between Renal Excretory Function and Proteinuria

\begin{tabular}{|c|c|c|c|c|c|}
\hline Day after exposure & $\begin{array}{c}\text { Blood urea } \\
(\mathrm{mg} / 100 \mathrm{ml})\end{array}$ & $\begin{array}{c}\text { Plasma } \\
\text { creatinine } \\
(\mathrm{mg} / 100 \mathrm{ml})\end{array}$ & $\begin{array}{c}\text { Creatinine } \\
\text { clearance } \\
(\mathrm{ml} / \mathrm{min})\end{array}$ & $\begin{array}{l}\text { Proteinuria } \\
\quad(g / 24 h)\end{array}$ & $\begin{array}{l}\text { Urine vol. } \\
(\mathrm{ml} / 24 \mathrm{hr})\end{array}$ \\
\hline $\begin{array}{r}1 \\
3 \\
13 \\
21 \\
27 \\
32\end{array}$ & $\begin{array}{l}115 \\
- \\
-\end{array}$ & $\begin{array}{r}\overline{6 \cdot 2} \\
15 \cdot 2 \\
13 \cdot 8 \\
13 \cdot 2 \\
11 \cdot 8\end{array}$ & $\begin{array}{l}-\overline{8.6} \\
1.8 \\
1.9 \\
6.0 \\
8.0\end{array}$ & $\begin{array}{l}- \\
\overline{0} \\
0.88 \\
0 \cdot 63 \\
1 \cdot 38 \\
1 \cdot 48\end{array}$ & $\begin{array}{r}2 \overline{035} \\
525 \\
630 \\
1830 \\
1250\end{array}$ \\
\hline \multicolumn{6}{|c|}{ Last peritoneal dialysis completed } \\
\hline $\begin{array}{r}40 \\
47 \\
54 \\
91 \\
126 \\
152 \\
229\end{array}$ & $\begin{array}{r}125 \\
119 \\
83 \\
30 \\
28 \\
\frac{26}{26}\end{array}$ & $\begin{array}{r}10.8 \\
6.3 \\
4.0 \\
2.0 \\
2 \cdot 2 \\
1.8\end{array}$ & $\begin{array}{c}8.0 \\
19.0 \\
20.0 \\
- \\
- \\
85.0 \\
-\end{array}$ & $\begin{array}{l}0.84 \\
0.56 \\
0.15 \\
0.30 \\
0.50 \\
\text { Nil } \\
\text { Nil }\end{array}$ & $\begin{aligned} 850 \\
1300 \\
1300 \\
1850 \\
1520 \\
1200 \\
970\end{aligned}$ \\
\hline
\end{tabular}




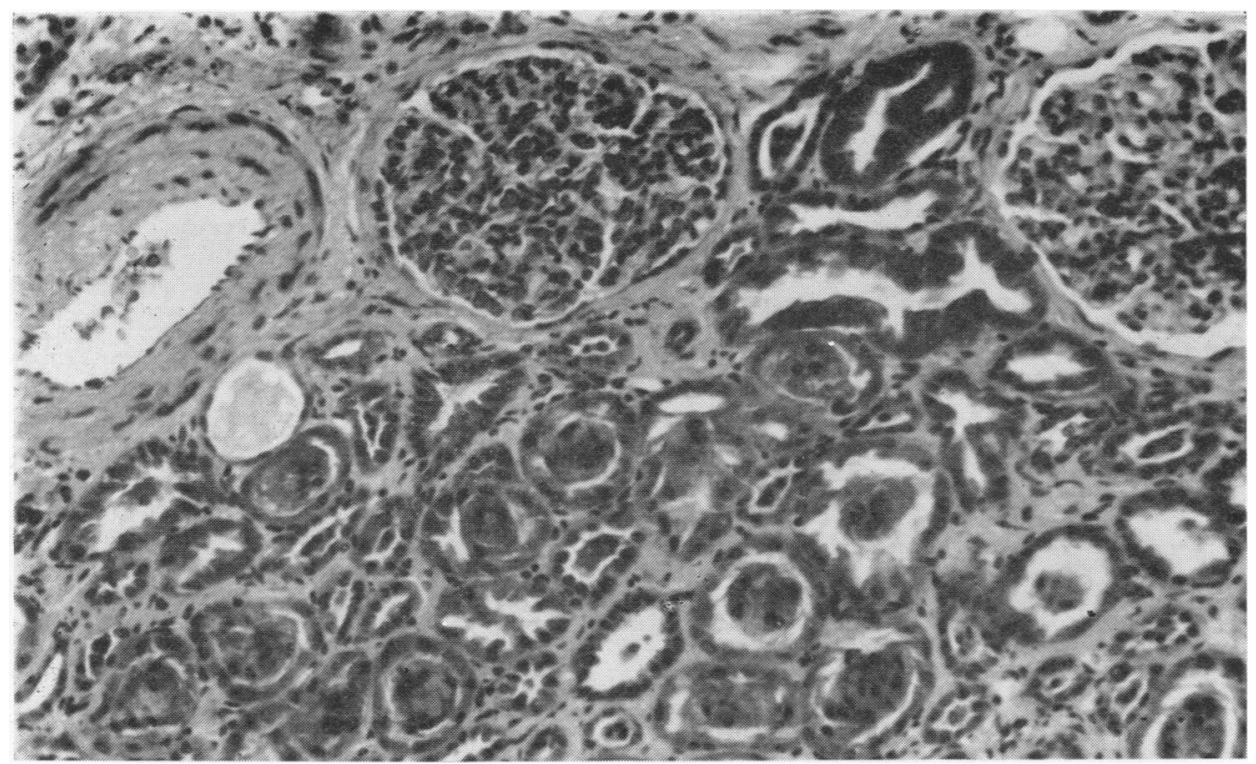

FIG. 2. Renal biopsy, arsine poisoning. Five months after exposure. Note hypercellularity of the glomerular tuft. There is separation of the tubules by fibrous tissue. Casts and debris are still present in some slightly dilated tubules (Masson's trichrome $\times 3$ ).

$100 \%$ mortality, although the source quoted by Muehrcke and Pirani (1968) for this information was possibly unable to offer the supportive therapy now available for acute renal failure.

The diagnosis should not be difficult if the environment is noted and the condition is suspected. Chemically, it may be very difficult to prove, for in the 'normal' circumstance of industrial arsine poisoning arsenic is an environmental contaminant and is always demonstrable in the nails and hair of workers, as it was in our patient. Pinto and his colleagues considered that there was no relationship between the arsenic content of the urine, the haemoglobinuria, and the degree of intoxication (Pinto, Petronella, Johns, and Arnold, 1950).

The appearance of haemoglobinuria was rapid, and the haemolytic process (Fig. 1) appeared to be self-limiting. Arsine is a strong reducing agent, with an affinity for haemoglobin. McKinstry and Hickes (1957) advocated exchange transfusion, and Buchanan (1962) referred to exchange transfusion as well as haemodialysis. Muehrcke and Pirani (1968) discussed the value of exchange transfusions and the failure of dialysis to remove the 'arsenichaemoglobin complex'. Serum albumin fails to pass an in-vitro semi-permeable membrane in significant quantities, but significant serum protein loss occurs in peritoneal dialysis (Berlyne, Jones, Hewitt, and Nilwarangkur, 1964). If anuria does not supervene, the toxic complex is presumably excreted. It is clear from the experience of Pinto and his colleagues
(1950) that haemolysis was a time-limited factor in their surviving cases.

Hepato-cellular damage is the least formidable of the presenting problems. Pinto and his colleagues (1950) refer to 'a suggestion of jaundice' in one of their 13 cases, and Macaulay and Stanley (1956) suggest that the pigmentation is due to free haemoglobin. In our patient there was a peculiar dusky cyanotic hue in the acute stage (Cecil and Loeb, 1967) but the serum bilirubin never rose above 2.5 $\mathrm{mg} / 100 \mathrm{ml}$ despite deep 'jaundice'. There was no persisting hepato-cellular damage on review at 12 months.

There is adequate explanation of the acute renal failure associated with arsine poisoning. Arsine is a direct tissue poison. The nephrotoxic effect of intravascular haemolysis would be implicated by the haemolysis releasing the toxic 'arsine-haemoglobin complex' (Muehrcke and Pirani, 1968). Muehrcke and Pirani's work on the serial histology of the condition is full, and we cannot presume to contribute to this facet. Interstitial damage, persisting beyond the recovery of acute tubular necrosis, is the expected histo-pathology of arsine poisoning. A biopsy was not taken from our patient until five months after the accident. Then the histological picture closely resembled that described by Muehrcke and Pirani at 161 days, with dominant interstitial damage and tubular dystrophy. By this time the blood urea was within normal limits. At the 12-month review of the case, all the measures of 
renal function were normal, and the patient had returned to work. It is regrettable that a further biopsy was not obtainable. As the latest state appears to indicate full function, it is difficult to see how the injury will be life-shortening. It is presumed that there is not a continuous process here, as in nephritis or pyelonephritis. However, the problem of elucidation of the aetiology of the picture of interstitial fibrosis is well recognized. This is commonly translated by pathologists as 'chronic pyelonephritis' when there is no evidence of bacterial influence. It may be that interstitial nephritis is a progressive condition (as we believe 'chronic pyelonephritis' to be), irrespective of aetiology (Heptinstall, 1967; Leading article, 1968).

It is generally accepted that recovery from acute tubular necrosis is full and that the prognosis for life is good. However, it has been demonstrated that recovery tends to leave a deficiency of glomerular filtration rate (Briggs, Kennedy, Young, Luke, and Gray, 1967). The significance of the late resolution of the concentrating deficiency in the present case is not known. The absolute recovery from acute tubular necrosis was also challenged by Muehrcke and his colleagues when they related the duration of anuria to ultimate function in a series of cases (Muehrcke, Rosen, Pirani, and Kark, 1964). It is probable that the long-term effect of acute tubular necrosis is not known, although in one series Briggs and his colleagues (1967) suggested that up to four years after initial recovery there was no subsequent deterioration.

The superficial phlebitis in the acute stage was of interest. The patient has significant bilateral varicose veins of the lower leg. These vessels were prominent, outlined to form a coarse reticular pattern, and tender to touch. It is tempting to postulate a relationship between the transitory phlebitis and the products of intravascular haemolytic break-down, with the duration of which the phlebitis was temporally linked.
We are very grateful for the close co-operation and great interest exhibited by the Department of Haematology, Kingston General Hospital, Hull, in particular by Dr. L. S. Sacker, haematologist.

\section{References}

Berlyne, G. M., Jones, J. H., Hewitt, V., and Nilwarangkur, S. (1964). Protein loss in peritoneal dialysis. Lancet, 1, 738-741.

Briggs, J. D., Kennedy, A. C., Young, L. N., Luke, R. G., and Gray, M. (1967). Renal function after acute tubular necrosis. Brit. med. J., 3, 513-516.

Browning, E. (1961). Toxicity of Industrial Metals. Butterworths. London.

Buchanan, W. D. (1962). Toxicity of Arsenic Compounds. Elsevier, Amsterdam and London.

Cecil, R. L., and Loeb, R. F. (1967). Cecil-Loeb Textbook of Medicine, 12 th ed., ed. Beeson, P. B., and McDermott, W. Saunders, Philadelphia.

Doig, A. T. (1958). Arseniuretted hydrogen poisoning in tank cleaners. Lancet, 2, 88-92.

Heptinstall, R. H. (1967). The limitations of the pathological diagnosis of chronic pyelonephritis. In Renal Disease, 2nd ed., pp. 350-381. Ed. Black, D. A. K. Blackwell, Oxford.

Hunter, D. (1962). The Diseases of Occupations, 3rd ed. English Universities Press, London.

Josephson, C. J., Pinto, S. S., and Petronella, S. J. (1951). Arsine: Electro-cardiographic changes produced in acute human poisoning. Arch. industr. Hyg., 4, 43-52.

Leading article (1968). Pyelonephritis without bacteria. Lancet, 2, 1125-1126.

Macaulay, D. B., and Stanley, D. A. (1956). Arsine poisoning. Brit. J. industr. Med., 13, 217-221.

McKinstry, W. J., and Hickes, J. M. (1957). Emergency-arsine poisoning. Arch. intern. Med., 100, 34-43.

Ministry of Labour (1966a). Dust and Fumes in Factory Atmospheres, 3rd ed. Safety, Health and Welfare Booklet, New Series No. 8 H.M.S.O., London.

(1966b). Methods for the Detection of Toxic Substances in Air Booklet No. 9: Arsine. H.M. Factory Inspectorate. H.M.S.O., London.

Muehrcke, R. C., and Pirani, C. L. (1968). Arsine-induced anuria, a correlative clinicopathological study with electron microscopic observations. Ann. intern. Med., 68, 853-866.

- Rosen, S., Pirani, C. L., and Kark, R. M. (1964). Renal lesions in patients recovering from acute renal failure. J. Lab. clin. Med., 64, 888.

Pinto S. S., Petronella, S. J., Johns D. R., and Arnold, M. F. (1950). Arsine poisoning. A study of 13 cases. Arch. industr. Hyg., 1, 437-451.

Wrong, O., and Davies, J. E. F. (1959). The excretion of acid in renal disease. Quart. J. Med., 28, 259-313.

Received for publication June 3, 1969. 